\title{
Effects of milk proteins and posttranslational modifications on noncoagulating milk from Swedish Red dairy cattle
}

\author{
K. Nilsson, ${ }^{1 *}$ L. Buhelt Johansen, ${ }^{2}$ D. J. de Koning, ${ }^{3}$ S. I. Duchemin, ${ }^{3}$ M. Stenholdt Hansen, ${ }^{2}$ H. Stålhammar, ${ }^{4}$ \\ H. Lindmark-Månsson, ${ }^{1}$ M. Paulsson, ${ }^{1}$ W. F. Fikse, ${ }^{5}$ and M. Glantz ${ }^{1}$ \\ ${ }_{1}^{1}$ Department of Food Technology, Engineering and Nutrition, Lund University, PO Box 124, SE-221 00 Lund, Sweden \\ ${ }^{2}$ Arla Foods amba, Agro Food Park 19, DK-8200 Aarhus N, Denmark \\ ${ }^{3}$ Department of Animal Breeding and Genetics, Swedish University of Agricultural Sciences, PO Box 7023, SE-750 07 Uppsala, Sweden \\ ${ }^{4}$ VikingGenetics, PO Box 64, SE-532 21 Skara, Sweden \\ ${ }^{5}$ Växa Sverige, PO Box 288, SE-751 05 Uppsala, Sweden
}

\section{ABSTRACT}

Milk that does not coagulate after rennet addition, also called noncoagulating (NC) milk, is unwanted in cheese production due to prolonged processing time. Amounts of whey and casein proteins, genetic variants, as well as posttranslational modifications (PTM) of proteins are all contributing factors in rennet-induced coagulation of milk. In this study, we conducted a wideranging investigation of milk proteins in milk samples from 616 Swedish Red dairy cattle using liquid chromatography-high resolution mass spectrometry. Relative concentration of proteins, genetic variants, and PTM were compared between NC milk and coagulating milk. The PTM investigated were phosphorylation of caseins and glycosylation of $\kappa$-casein. Several genetic variants and PTM were found, including rare phosphorylation variants of the $\alpha_{S}$-caseins. Genetic variants were found to effect the expressed amount of different proteins. Further, the effect of protein amounts and PTM on a binary NC milk trait was modeled using a generalized linear model. The model showed that NC milk significantly correlated with higher relative concentrations of $\alpha$-lactalbumin and $\beta$-casein and lower relative concentrations of $\beta$-lactoglobulin and $\kappa$-casein. Regarding PTM of caseins, an effect on NC milk from a lower relative concentration of $\alpha_{S_{1}}$-casein with 8 phosphate groups were found, even though an effect from total relative concentration of $\alpha_{\mathrm{S}^{-}}$-casein was not found. This study has provided insights into protein variants and PTM important for NC milk to improve this undesirable property.

Key words: milk coagulation, protein profile, genetic variants, posttranslational modifications

Received February 13, 2020.

Accepted April 6, 2020.

*Corresponding author: kajsa.nilsson@food.lth.se

\section{INTRODUCTION}

The ability of milk to coagulate after addition of rennet is a crucial step in cheese production. We have previously shown that Swedish Red dairy cattle (RDC) have a high prevalence of individuals (18\%) that produce noncoagulating (NC) milk (Nilsson et al., 2019). This high prevalence affects rennet coagulation properties, and thereby cheese production. Thus, it is of high interest for cheese-producing dairies to eliminate NC milk. A possible explanation for the inability of the milk to coagulate is the protein composition and genetic variants of milk proteins. However, there are only a few detailed studies on the protein profile for Swedish RDC.

There are 6 main proteins in bovine milk: $\alpha$-LA, $\beta-\mathrm{LG}, \alpha_{\mathrm{S} 1}-\mathrm{CN}, \alpha_{\mathrm{S} 2}-\mathrm{CN}, \beta-\mathrm{CN}$, and $\kappa-\mathrm{CN}$. These proteins have different genetic variants due to variations in the amino acid sequences, and the variants can differ between breeds (Caroli et al., 2009). Additionally, posttranslational modifications (PTM) of proteins, such as phosphorylation of $\mathrm{CN}$ and glycosylation of $\kappa-\mathrm{CN}$, occur naturally in milk and are crucial for micelle formation and stability. Two different amino acids, Ser and Thr, are susceptible to PTM in milk (Holland and Boland, 2014). The reference type of $\alpha_{\mathrm{S}_{1}} \mathrm{CN}$ is $\alpha_{\mathrm{S}^{-}} \mathrm{CN}$ $B$-8P, where P indicates phosphorylation (Farrell et al., 2004 ), but the 9P isoform has been found in previous studies (Bijl et al., 2014; Fang et al., 2016; Ketto et al., 2017). Additionally, a more uncommon 7P isoform has been detected (Léonil et al., 1995). For $\alpha_{S_{2}} \mathrm{CN}$, the reference is $A-11 \mathrm{P}$ (Farrell et al., 2004), and the protein was previously thought to have 4 phosphorylation forms, 10P through 13P (Holland and Boland, 2014). However, Fang et al. (2016) reported that they discovered an additional 3 isoforms, 9P, 14P, and 15P. The reference of $\beta-\mathrm{CN}$ is $\beta-\mathrm{CN} A^{2}-5 \mathrm{P}$, although the $4 \mathrm{P}$ isoform is also found. The reference for $\kappa-\mathrm{CN}$ is $\kappa-\mathrm{CN}$ $A-1 \mathrm{P}$ (Farrell et al., 2004), although $2 \mathrm{P}$ and $3 \mathrm{P}$ iso- 
forms of $\kappa$-CN have been identified in previous studies (Vreeman et al., 1986; Minkiewicz et al., 1996; Jensen et al., 2012a). Besides phosphorylation, up to 6 glycans can attach to $\kappa-\mathrm{CN}$ (Vreeman et al., 1986), and there are 5 different known glycans (Saito and Itoh, 1992). However, different PTM and genetic variants have not, to our knowledge, been studied in a larger Swedish RDC population.

Rennet-induced coagulation of milk is the first step in cheese production, when $\kappa-\mathrm{CN}$ is hydrolyzed between $\mathrm{Phe}_{105}$ and $\mathrm{Met}_{106}$ by addition of chymosin (Fox and McSweeney, 2017). The aggregation of CN micelles occurs when about $80 \%$ of $\kappa$-CN is hydrolyzed (Sandra et al., 2007) and the para-k-CN that is still part of the $\mathrm{CN}$ micelle aggregates with the help of ionic $\mathrm{Ca}$, which is the basis of the gel network (Guinee, 2016). Milk coagulation properties (MCP) are affected by different components in milk. Amounts of protein, genetic variants, and PTM of proteins have all been found to affect MCP (Bijl et al., 2014; Ketto et al., 2017; Amalfitano et al., 2019). This is also true for NC milk, which has been associated with lower $\beta-\mathrm{LG}$ and $\kappa$-CN contents (Hallén et al., 2010; Jensen et al., 2012b; Gustavsson et al., 2014c). Furthermore, NC milk was associated with a lower frequency of $\beta$-CN genotype $A^{1} A^{1}$ and higher frequencies of $\beta-\mathrm{CN} A^{2} A^{2}$, $\kappa-\mathrm{CN} A A$, and $\kappa-\mathrm{CN}$ $E E$ compared with coagulating milk (Poulsen et al., 2013). However, studies using PTM in relation to NC milk are scarce and are limited to studies comparing contents between coagulation groups. The aim of this study was to determine the protein profile (i.e. relative concentrations of individual proteins, genetic variants, and PTM) in milk samples from Swedish RDC, and associate these with the coagulation ability of the same sample. Further, effects of proteins and PTM on NC milk were evaluated using statistical models to find factors that could be associated with $\mathrm{NC}$ milk. The results can be used to increase the understanding of the mechanism behind NC milk and provide valuable information for breeding and dairy companies to prevent further inheritance.

\section{MATERIALS AND METHODS}

\section{Milk Collection, Composition and Rheological Evaluation}

Milk samples were collected from 724 individual Swedish RDC during the stable periods in 2015 to 2016 and 2016 to 2017 from 31 conventional farms in the south of Sweden. The cows were milked twice per day and the milk samples were collected during morning milking. One milk sample from each cow was collected and the samples were cooled and transported to Lund
University on the same day as collection. All cows were fed according to standard practices. Data regarding the cow's parity, milk yield, and DIM were collected from the Swedish national cow database (Växa Sverige, Sweden). Milk was centrifuged to obtain skim milk samples $\left(2,000 \times g, 4^{\circ} \mathrm{C}, 30 \mathrm{~min}\right)$ and either analyzed directly or frozen at $-18^{\circ} \mathrm{C}$ for later analyses. On the day of sampling, whole milk samples were sent to a certified dairy analysis laboratory (Eurofins Steins Laboratorium AB, Jönköping, Sweden) to determine the fat, protein, lactose, and total Ca contents, as well as SCC. Fat, protein, and lactose contents were determined using Fourier transform infrared spectroscopy, total Ca content was determined using inductively coupled plasma atomic emission spectroscopy, and SCC was analyzed using fluorescent flow cytometry. Only milk samples with an SCC of $<300,000$ cells $/ \mathrm{mL}$ were included in further analyses. Casein micelle size, ionic $\mathrm{Ca}$, and $\mathrm{pH}$ were measured on fresh skim milk. Casein micelle size was measured using laser light scattering (Mastersizer 2000, Malvern Instruments, Malvern, UK) and the volume-weighted diameter $(\mathrm{D}[4,3])$ was obtained from the software. Ionic $\mathrm{Ca}$ was measured on a subset of samples at $32^{\circ} \mathrm{C}$ using a Ca electrode (9720BNWP, Thermo Fisher Scientific, Waltham, MA) and $\mathrm{pH}$ was measured at ambient temperature using a $\mathrm{pH}$ meter (744, Metrohm Nordic AB, Bromma, Sweden). A more detailed explanation of the sampling procedure and the compositional analyses can be found in Nilsson et al. (2019).

Fresh skim milk samples were analyzed to determine their rennet-induced coagulation properties using a free oscillation rheometer, ReoRox4 (MediRox AB, Nyköping, Sweden) as described in Nilsson et al. (2019). Briefly, $5 \%$ lactic acid was added to skim milk to adjust $\mathrm{pH}$ to 6.5 before the samples were heated in a water bath at $32^{\circ} \mathrm{C}$ for $30 \mathrm{~min}$. After chymosin addition to a final concentration of 0.09 international milk clotting unit/mL of milk (CHY-MAX Plus, 200 international milk clotting unit/mL, Chr Hansen A/S, Hørsholm, Denmark), the recording started and continued for 45 min. Coagulation time was defined as the time when the phase angle equals $45^{\circ}$; if the phase angle had not reached $45^{\circ}$ after $40 \mathrm{~min}$, the samples were defined as NC.

\section{Protein Profiling}

Milk samples were analyzed for protein composition using liquid chromatography-high resolution mass spectrometry, according to the method adapted from Rauh et al. (2015). The 200- $\mu \mathrm{L}$ samples of whole milk from each cow were thawed, and then the protein in the samples was dissolved in a reduction buffer, containing 20 
$\mu \mathrm{L}$ of $0.5 M$ dithioerythritol (Sigma-Aldrich, St. Louis, $\mathrm{MO}$ ), and $1 \mathrm{~mL}$ of $100 \mathrm{~m} M$ trisodium citrate (Merck, Darmstadt, Germany) and $6 M$ urea (Sigma-Aldrich). The reaction between the milk and the reduction buffer was ongoing for $60 \mathrm{~min}$ at $30^{\circ} \mathrm{C}$.

The samples were then centrifuged at $16,100 \times g$ at $5^{\circ} \mathrm{C}$ for $10 \mathrm{~min}$, and $200 \mu \mathrm{L}$ of the supernatant was used for analysis. A $5-\mu \mathrm{L}$ sample was injected into the 1290 LC coupled to a 6230 HRMS system (Agilent Technologies, Santa Clara, CA). For the column, we used a Poroshell 120 SB-C18 $2.1 \times 150 \mathrm{~mm}, 2.7 \mu \mathrm{m}$, as well as a guard column $(2.1 \times 15 \mathrm{~mm}$; Agilent Technologies $)$. Two buffers were used, buffer A and buffer B. Buffer A consisted of Milli-Q (Ultra-Clear TWF, Siemens, Munich, Germany) water with $0.05 \%$ (vol/vol) trifluoroacetic acid (Thermo Fisher Scientific, Waltham, MA) and buffer B consisted of acetonitrile (Rathburn, Walkerburn, UK) with $0.1 \%$ (vol/vol) trifluoroacetic acid. The column temperature was set to $40^{\circ} \mathrm{C}$, and a linear gradient from $34 \%$ to $47 \%$ of buffer B from 4 to 19 min was applied at a flow rate of $0.35 \mathrm{~mL} / \mathrm{min}$ with UV detection at $214 \mathrm{~nm}$.

Mass spectrometry detection was done with an electrospray ionization time-of-flight mass spectrometer (Agilent 6230B Accurate mass detector, Agilent Technologies). The MS scans were continuously recorded between a mass-to-charge ratio $(\mathrm{m} / \mathrm{z})$ from 450 to 3,200 in 2-GHZ extended dynamic positive mode. The drying gas temperature in the electrospray ionization time-offlight mass spectrometer was $325^{\circ} \mathrm{C}$, the flow rate was $10 \mathrm{~L} / \mathrm{min}$, and the nebulizer pressure was 35 psi. The sheath gas temperature was $300^{\circ} \mathrm{C}$ with a flow rate of $7 \mathrm{~L} / \mathrm{min}, 3,500 \mathrm{~V}$ was applied to the capillary, and the fragmentor energy was set to $200 \mathrm{~V}$.

\section{Data Analysis}

Data analysis was performed with MassHunter software (version B 6.01, Agilent Technologies). The obtained mass spectra and UV chromatograms were further analyzed by MassHunter and Profinder (prerelease version B.08.00 Service Pack 1; Agilent Technologies, Santa Clara, CA) software. The relative concentrations of the whey and CN proteins were obtained by dividing the integrated peak area of each protein with the total integrated peak area in the $\mathrm{UV}_{214 \mathrm{~nm}}$ chromatogram for each milk sample. Milk proteins were eluted in the following order: glycosylated $\kappa-\mathrm{CN} A / E / B, \kappa-\mathrm{CN} A / E$, monoglycosylated $\kappa-\mathrm{CN} B, \kappa-\mathrm{CN} B, \alpha_{\mathrm{S}^{2}} \mathrm{CN}, \alpha_{\mathrm{S} 1}-\mathrm{CN}$, $\beta$-CN, $\alpha-\mathrm{LA}, \beta-\mathrm{LG} B$, and $\beta$-LG $A$. The UV chromatograms were also used to calculate the frequency of degraded proteins. Peaks in the UV chromatograms before glycosylated $\kappa$-CN $A / E$, peaks between $\alpha_{S_{2}}-\mathrm{CN}$ and $\alpha_{\mathrm{S}_{1}} \mathrm{CN}$, as well as peaks between $\beta-\mathrm{CN}$ and $\alpha$-LA, were all regarded as degraded proteins. Samples were discarded due to too much proteolytic activity if the frequency of degraded proteins was $>10 \%$ of total protein area. This resulted in 616 milk samples that were further analyzed in this study.

Genetic variants and PTM were determined by comparing obtained masses with the Uniprot database (https://www.uniprot.org/) according to the following identifications: $\alpha$-LA (Uniprot P00711), $\beta$-LG (UniProt $\mathrm{P} 02754), \alpha_{\mathrm{S} 1}-\mathrm{CN}$ (Uniprot P02662), $\alpha_{\mathrm{S} 2}-\mathrm{CN}$ (UniProt P02663), $\beta-\mathrm{CN}$ (UniProt P02666), $\kappa-\mathrm{CN}$ (UniProt P02668). The masses used can be seen in Table 1. The relative concentrations of each genetic variant and PTM were determined by the peak area of each protein divided by total peak area of that specific protein. Different protein variants have different response factors (Bonfatti et al., 2008). Therefore, to avoid false-positive results of genetic variants, a threshold of $25 \%$ of the specific protein area in the extracted ion envelopes had to be achieved to be counted as a genetic variant. Phosphorylated forms of CN proteins were obtained by adding or subtracting the mass of $\mathrm{P}(79.99 \mathrm{Da})$ to the predominant masses in Table 1 . The following phosphorylations were included in the analysis: $\kappa-\mathrm{CN} 1-3 \mathrm{P}$, $\alpha_{\mathrm{S}-\mathrm{CN}}$ 7-9P, $\beta-\mathrm{CN} 4-5 \mathrm{P}$, and $\alpha_{\mathrm{S}^{2}} \mathrm{CN}$ 9-15P. The extended phosphorylated forms of $\alpha_{\mathrm{S}^{2}} \mathrm{CN}$ were added based on the study of Fang et al. (2016). Up to triple glycosylation of $\kappa-\mathrm{CN}$ was analyzed using the masses of 5 glucans known to be attached to $\mathrm{k}-\mathrm{CN}$ (Saito and Itoh, 1992; Farrell et al., 2004). The masses used were the same as earlier publications, where the mass of 1 water molecule $(18 \mathrm{Da})$ was removed to calculate mass of glycosylated $\kappa-\mathrm{CN}$, and glycans were denoted a through e based on earlier publications (Jensen et al., 2015) as follows: a) $\mathrm{N}$-acetyl-galactosamine (GalNAc), $221.2 \mathrm{Da}$; b) galactose (Gal) $\beta(1-3)$ GalNAc, 383.3 Da; c) $N$-acetyl-neuraminic acid (NeuAc) $\alpha(2-3) \mathrm{Gal} \beta(1-3)$ GalNAc, 674.6 Da; d) Galß(1-3)[NeuAco (2-6)] GalNAc,

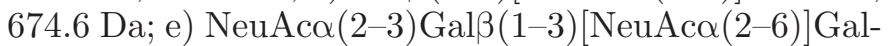
NAc, 965.6 Da. To obtain the relative concentrations of the different proteins in milk, total protein percentage obtained from infrared spectroscopy was multiplied with the relative protein concentrations from the liquid chromatography-high resolution mass spectrometry measurement.

\section{Statistical Analysis}

A generalized linear model was used to estimate the effect of genotype on relative protein concentration (model [1]). Only genotypes that were found in $>6 \%$ of the milk samples were included. 
Table 1. Description of protein variants, including genetic variants, and their respective masses

\begin{tabular}{|c|c|}
\hline Protein variant & Mass (Da) \\
\hline$\alpha-\mathrm{LA} B$ & 14,186 \\
\hline$\beta$-LG $D$ & 18,280 \\
\hline$\beta-\mathrm{LG} B$ & 18,281 \\
\hline$\beta-\mathrm{LG} A$ & 18,367 \\
\hline$\kappa-\mathrm{CN} G^{1} 1 \mathrm{P}$ & 18,952 \\
\hline$\kappa-\mathrm{CN} F^{2} 1 \mathrm{P}$ & 18,986 \\
\hline$\kappa-\mathrm{CN} G^{2} 1 \mathrm{P}$ & 18,993 \\
\hline$\kappa-\mathrm{CN} B$ 1P & 19,005 \\
\hline$\kappa-\mathrm{CN} E 1 \mathrm{P}$ & 19,007 \\
\hline$\kappa-\mathrm{CN} C 1 \mathrm{P}$ & 19,018 \\
\hline$\kappa-\mathrm{CN} I / F^{1} 1 \mathrm{P}$ & 19,021 \\
\hline к-CN $A$ 1P & 19,037 \\
\hline$\kappa-\mathrm{CN} H$ 1P & 19,049 \\
\hline$\kappa-\mathrm{CN} J 1 \mathrm{P}$ & 19,074 \\
\hline$\alpha_{\mathrm{S} 1}-\mathrm{CN} A 8 \mathrm{P}$ & 22,055 \\
\hline$\alpha_{\mathrm{S}_{1}}-\mathrm{CN} C 8 \mathrm{P}$ & 23,542 \\
\hline$\alpha_{\mathrm{S} 1}-\mathrm{CN} D 8 \mathrm{P}$ & 23,584 \\
\hline$\alpha_{\mathrm{S}^{-}-} \mathrm{CN} B 8 \mathrm{P}$ & 23,614 \\
\hline$\beta-\mathrm{CN} H^{2} 5 \mathrm{P}$ & 23,894 \\
\hline$\beta-\mathrm{CN} H^{1} 5 \mathrm{P}$ & 23,930 \\
\hline$\beta-\mathrm{CN} C 4 \mathrm{P}$ & 23,942 \\
\hline$\beta-\mathrm{CN} I 5 \mathrm{P}$ & 23,965 \\
\hline$\beta-C N E 5 \mathrm{P}$ & 23,982 \\
\hline$\beta-\mathrm{CN} A^{2} 5 \mathrm{P}$ & 23,983 \\
\hline$\beta-\mathrm{CN} A^{3} 5 \mathrm{P}$ & 23,992 \\
\hline$\beta-\mathrm{CN} A^{1} 5 \mathrm{P}$ & 24,023 \\
\hline$\beta-\mathrm{CN} D 4 \mathrm{P}$ & 24,025 \\
\hline$\alpha_{\mathrm{S}_{2}-} \mathrm{CN} D 11 \mathrm{P}$ & 24,033 \\
\hline$\beta-\mathrm{CN} F 5 \mathrm{P}$ & 24,039 \\
\hline$\beta-\mathrm{CN} B 5 \mathrm{P}$ & 24,092 \\
\hline$\alpha_{\mathrm{S}^{-}} \mathrm{CN} C 11 \mathrm{P}$ & 25,198 \\
\hline$\alpha_{\mathrm{S}_{2}-} \mathrm{CN} A 11 \mathrm{P}$ & 25,228 \\
\hline
\end{tabular}

${ }^{1}$ The mass for the phosphoryl group (P; 79.99 Da) was added or subtracted to find further phosphorylations in $\kappa-\mathrm{CN}(1-3 \mathrm{P}), \alpha_{\mathrm{S1}}-\mathrm{CN}(7-$ $9 \mathrm{P}), \beta-\mathrm{CN}(4-5 \mathrm{P})$, and $\alpha_{\mathrm{S} 2}-\mathrm{CN}(9-15 \mathrm{P})$.

$$
\begin{aligned}
Y_{i j k l m}= & \mu+\text { herd }_{i}+\text { parity }_{j}+\text { DIM }+\beta \text { LGgen }_{k} \\
& +\beta C \text { Ngen }_{l}+\kappa C N g e n_{m}+e_{i j k l m},
\end{aligned}
$$

where $Y_{i j k l m}$ is the relative concentration of $\alpha$-LA, $\beta$-LG, $\alpha_{\mathrm{S} 1}-\mathrm{CN}, \alpha_{\mathrm{S} 2}-\mathrm{CN}, \beta-\mathrm{CN}$, or $\kappa-\mathrm{CN}$; herd is fixed $(i=1,2$, $\ldots, 30)$; parity is fixed $(j=1,2,3)$, where parities 3 to 8 were grouped together; $D I M$ is a covariate; $\beta L G g e n$ is the fixed effect of genotype for $\beta$-LG $(k=A A, A B$, $B B) ; \beta C N$ gen is the fixed effect of genotype for $\beta-\mathrm{CN}$ ( $\left.l=A^{1} A^{1}, A^{1} A^{2}, A^{2} A^{2}\right) ; \kappa C N g e n$ is the fixed effect of genotype for $\kappa-\mathrm{CN}(m=A A, A B, A E, B B)$; and $e_{i j k l m}$ is the random residual effect.

A generalized linear model was also used to evaluate the influence of herd, parity, DIM, and relative concentrations of proteins on a binary NC trait (model [2]). To further investigate the effect of PTM of proteins on NC milk, a second generalized linear model was used (model [3]), where the $\mathrm{CN}$ proteins were instead added as relative concentration of PTM type. Only PTM that were found in $>10 \%$ of the samples were included in model [3].

$$
\begin{gathered}
Y_{i j}=\mu+\text { herd }_{i}+\text { parity }_{j}+D I M+\alpha L A+\beta L G \\
+\alpha_{S 1} C N+\alpha_{S 2} C N+\beta C N+\kappa C N+e_{i j}, \\
Y_{i j}=\mu+\text { herd }_{i}+\text { parity }_{j}+D I M \\
+\alpha L A+\beta L G+\alpha_{S 1} C N_{7 \mathrm{P}}+\alpha_{S 1} C N_{8 \mathrm{P}}+\alpha_{S 1} C N_{9 \mathrm{P}} \\
+\alpha_{S 2} C N_{10 \mathrm{P}}+\alpha_{S 2} C N_{11 \mathrm{P}}+\alpha_{S 2} C N_{12 \mathrm{P}}+\alpha_{S 2} C N_{13 \mathrm{P}} \\
+\beta C N_{5 \mathrm{P}}+\kappa C N_{1 \mathrm{P}, \mathrm{UG}}+\kappa C N_{1 \mathrm{P}, 1 \mathrm{G}(\mathrm{c} / \mathrm{d})}+\kappa C N_{1 \mathrm{P}, 1 \mathrm{G}(\mathrm{e})} \\
+\kappa C N_{1 \mathrm{P}, 2 \mathrm{G}(\mathrm{e}, \mathrm{e})}+\kappa C N_{2 \mathrm{P}, \mathrm{UG}}+\kappa C N_{2 \mathrm{P}, 1 \mathrm{G}(\mathrm{e})}+e_{i j},
\end{gathered}
$$

where $Y_{i j}$ is the binary $\mathrm{NC}$ trait $(1=\mathrm{NC}$ and $0=$ coagulating); herd is fixed ( $i=1,2, \ldots, 30)$; parity is fixed $(j=1,2,3)$, where parities 3 to 8 were grouped together; DIM is covariate; $\alpha L A, \beta L G, \alpha_{S 1} C N, \alpha_{S 2} C N$, $\beta C N$, and $\kappa C N$ are the different relative concentrations of the proteins, which are covariates, where $\mathrm{P}$ is phosphorylation number, $\mathrm{G}$ is glycosylation number, and UG means unglycosylated; and $e_{i j}$ is the random residual effect. From the generalized linear models, odds ratios were obtained by the exponential parameter estimate. The odds ratios indicates if an increase in relative concentration of protein with 1 percentage point is associated with higher or lower odds of having $\mathrm{NC}$ milk. When the odds ratio is $<1$, the odds of $\mathrm{NC}$ milk decreases and vice versa for odds ratio $>1$, whereas an odds ratio of 1 indicates no relationship. All statistics were performed using IBM SPSS Statistics v. 24 (IBM Analytics, Armonk, NY).

\section{RESULTS AND DISCUSSION}

\section{Genotype and Allele Frequencies}

Descriptive statistics of the milk samples (MCP and composition) can be found in Table 2. Frequencies of genotypes and alleles can be found in Table 3 . For $\alpha$-LA and $\alpha_{S_{2}}$ CN, we only found 1 allele each, $B$ and $A$, respectively. For the other proteins, the most common alleles were $\beta$-LG $B, \alpha_{\mathrm{S} 1}-\mathrm{CN} B, \beta-\mathrm{CN} A^{2}$, and $\kappa-\mathrm{CN} A$. The most common genotypes were $\beta-\mathrm{LG} A B$, $\alpha_{\mathrm{S} 1} \mathrm{CN} B B, \beta-\mathrm{CN} A^{1} A^{2}$, and $\kappa-\mathrm{CN} A A$. These alleles and genotypes were most common for all samples combined, but also for the 2 coagulation groups separately. Swedish RDC is a result of mixed breeding between Swedish Red Breed, Finnish Ayrshire, Norwegian Red, Danish Red, and Canadian Ayrshire. Common genetic variants in these Nordic red breeds are $\beta$-LG $A$ and $B$, $\alpha_{\mathrm{S} 1}-\mathrm{CN} B, \beta-\mathrm{CN} A^{1}$ and $A^{2}$, as well as $\kappa-\mathrm{CN} A, B$, and $E$ (Lien et al., 1999; Gustavsson et al., 2014a; Ketto et al., 2017). The alleles we found in our study are consistent with other studies of Nordic red dairy breeds (Gustavsson et al., 2014a; Ketto et al., 2017; Poulsen 
Table 2. Descriptive statistics of rheological traits, milk composition, and production traits in the 2 coagulation groups

\begin{tabular}{|c|c|c|c|c|c|c|c|c|c|}
\hline Variable & \multicolumn{6}{|c|}{ Coagulation group } & & & \\
\hline Coagulation time (min) & 107 & $\geq 40^{1}$ & 0.08 & 509 & 13.30 & 0.27 & 18.77 & 13.15 & 70 \\
\hline Curd firming rate $(\mathrm{Pa} / \mathrm{min})$ & 107 & 0.01 & 0.00 & 509 & 4.56 & 0.21 & 3.77 & 4.55 & 121 \\
\hline Gel strength $(\mathrm{Pa})$ & 107 & 0.43 & 0.19 & 509 & 232.79 & 5.70 & 192.42 & 146.35 & 76 \\
\hline Parity & 107 & 1.73 & 0.08 & 509 & 2.19 & 0.06 & 2.11 & 1.22 & 58 \\
\hline $\operatorname{SCC}(1,000 / \mathrm{mL})$ & 107 & 43 & 4 & 509 & 52 & 2 & 51 & 50 & 98 \\
\hline Fat $(\%)$ & 107 & 4.19 & 0.13 & 509 & 4.56 & 0.07 & 4.50 & 1.57 & 35 \\
\hline Lactose $(\%)$ & 107 & 4.67 & 0.02 & 509 & 4.63 & 0.01 & 4.64 & 0.21 & 5 \\
\hline Protein (\%) & 107 & 3.65 & 0.03 & 509 & 3.66 & 0.02 & 3.65 & 0.36 & 10 \\
\hline Total calcium (mg/kg) & 107 & 1,149 & 15 & 509 & 1,256 & 9 & 1,238 & 203 & 16 \\
\hline Ionic calcium $(\mathrm{mmol} / \mathrm{L})$ & 71 & 2.36 & 0.05 & 309 & 2.75 & 0.04 & 2.67 & 0.72 & 27 \\
\hline
\end{tabular}

${ }^{1}$ Coagulation time is right-censored data, as the measurement was terminated after $45 \mathrm{~min}$.

et al., 2017), with the exception of $\beta$-CN I. However, $\beta-\mathrm{CN}$ allele $I$ has been found in other red breeds, such as Italian Red Pied (Caroli et al., 2009), and is rare in the present study (Table 3 ).

Comparisons of the allele frequencies between $\mathrm{NC}$ and coagulating samples indicate that $\mathrm{NC}$ milk had higher $\beta$-LG $A$ and, consequently, lower $\beta$-LG $B$ frequencies compared with coagulating milk. Further, we found lower $\beta$-LG $A A$ and $A B$, and higher $\beta$-LG $B B$ genotype frequencies in $\mathrm{NC}$ milk samples compared with coagulating milk (Table 3 ). The differences in allele frequencies for $\beta$-LG agree with previous studies of NC milk (Jensen et al., 2012b; Gustavsson et al., 2014a; Poulsen et al., 2017). For $\beta$-CN, we found that NC samples had lower $A^{1}$ allele and $A^{1} A^{1}$ genotype, and higher $A^{2}$ allele and $A^{2} A^{2}$ genotype frequencies compared with coagulating milk, while the frequency of $\beta$-CN $A^{1} A^{2}$ was similar in both groups. The other alleles and genotypes were too rare to draw any conclusions from, however, as seen in Table 3; NC milk did not have any $\beta$-CN $B$ or $\beta$-CN $I$ alleles. The higher frequency of $\beta-\mathrm{CN} A^{2}$ allele in NC milk agrees with other publications (Jensen et al., 2012b; Gustavsson et al., 2014a; Poulsen et al., 2017). Raynes et al. (2015) suggested that the difference between $\beta-\mathrm{CN} A^{1}$ and $\beta$-CN $A^{2}$ has an effect on the structure of $\beta-\mathrm{CN}$. Additionally, other studies suggested that $\beta-\mathrm{CN} F$ variant has an effect on NC milk (Jensen et al., 2012b; Poulsen et al., 2016b). However, this could not be confirmed in our study due to the low frequency of allele $\mathrm{F}$ (Table 3 ). For $\kappa-\mathrm{CN}$, we found higher allele $A$ and lower allele $B$ frequencies in NC milk than in coagulating milk, and

Table 3. Frequencies of protein genotypes and alleles in all, noncoagulating (NC), and coagulating (C) milk samples

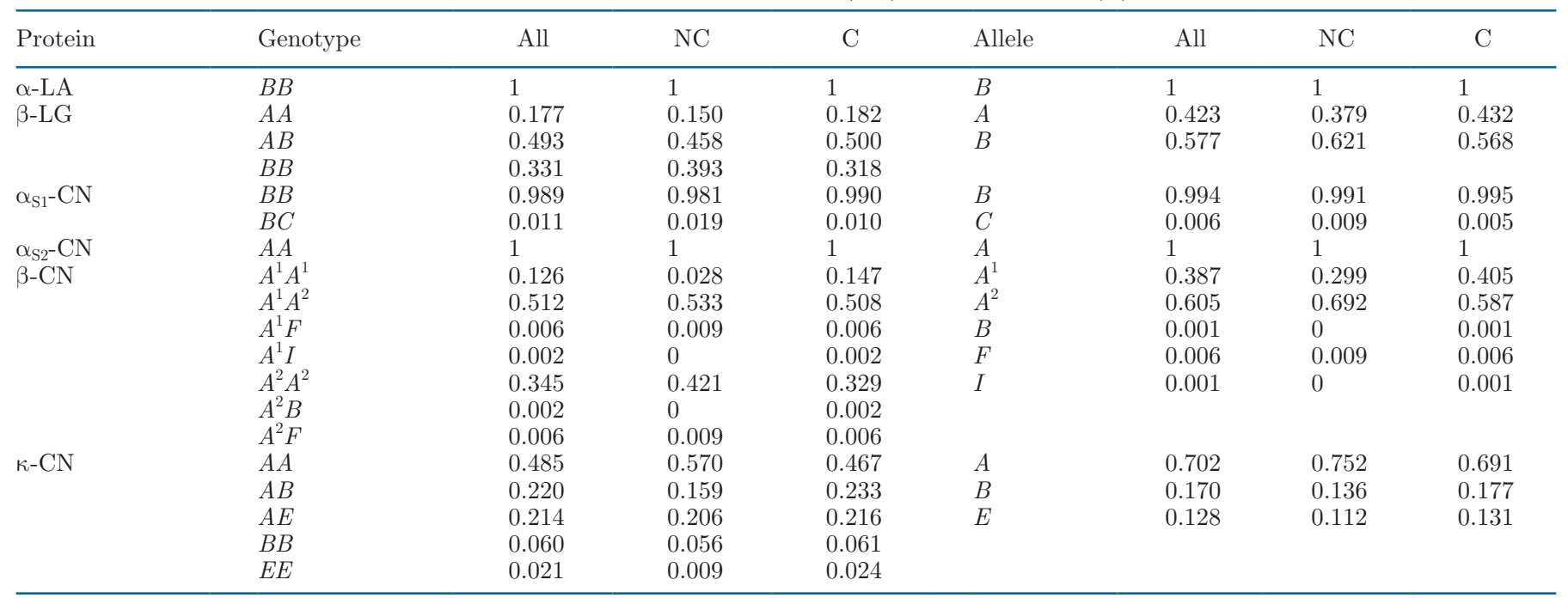


Table 4. Effects of herd, parity, DIM and genotypes on relative concentration of protein

\begin{tabular}{|c|c|c|c|c|c|c|}
\hline \multirow[b]{2}{*}{ Protein } & \multicolumn{3}{|c|}{ Trait } & \multicolumn{3}{|c|}{ Genotype } \\
\hline & Herd & Parity & DIM & $\beta-\mathrm{LG}$ & $\beta-\mathrm{CN}$ & $\kappa-\mathrm{CN}$ \\
\hline$\alpha-\mathrm{LA}$ & $* * *$ & $* * *$ & $* * *$ & $* * *$ & $* * *$ & * \\
\hline$\beta-\mathrm{LG}$ & $* * *$ & NS & $* * *$ & $* * *$ & $*$ & NS \\
\hline$\alpha_{\mathrm{S} 1}-\mathrm{CN}$ & $* * *$ & $*$ & $* * *$ & $* * *$ & NS & $* *$ \\
\hline$\alpha_{\mathrm{S} 2^{-}} \mathrm{CN}$ & $* * *$ & NS & $* * *$ & NS & $* * *$ & NS \\
\hline$\beta-\mathrm{CN}$ & $* * *$ & *** & $* * *$ & NS & NS & NS \\
\hline$\kappa-\mathrm{CN}$ & $* * *$ & $* * *$ & $* * *$ & NS & $* * *$ & $* * *$ \\
\hline
\end{tabular}

a similar frequency of $\kappa-\mathrm{CN} E$ in both groups. Further, for $\kappa$-CN genotypes, NC milk samples had a higher frequency of $A A$ and a lower frequency of $A B$ compared with coagulating milk. The frequencies of $\kappa-\mathrm{CN} A E$ and $\kappa-\mathrm{CN} B B$ were similar between the 2 groups, and $\kappa-\mathrm{CN}$ $E E$ genotype was rare in all samples (Table 3). Our observed result with a higher frequency of $\kappa-\mathrm{CN} A$ and $\kappa-\mathrm{CN} B$ in NC milk agrees with other studies (Jensen et al., 2012b; Gustavsson et al., 2014a; Poulsen et al., 2017). However, in those 3 other studies, NC milk had a higher frequency of $\kappa-\mathrm{CN} \mathrm{E}$ compared with the present study.

The different genotypes had no significant influence on NC milk when added in a generalized linear model together with relative concentration of protein (data not presented). Therefore, we concluded that there was a correlation between protein genotypes and expressed amount of protein in milk. From this conclusion, model [1] was used to study the effect of genotypes on relative concentration of protein (results can be seen in Table 4). Table 4 shows different genotypes affect different relative protein concentrations, and that only the relative concentration of $\beta-\mathrm{CN}$ is not significantly affected by any genotypes. In preliminary analyses, we expressed relative concentration as percent of protein instead of percent in milk, which resulted in more significant effects of genotype on relative protein concentration (data not shown). However, it is known that protein concentration has a large effect on coagulation ability and that protein concentration varies between individual cows (Walstra et al., 2006; Jõudu et al., 2008; Gustavsson et al., 2014b). Therefore, by expressing the relative concentrations as percent of milk, more reliable comparisons between the samples were obtained in this study. Other studies have also showed an effect of genotype on expressed relative concentrations of proteins in milk (Heck et al., 2009; Poulsen et al., 2017) and amount of proteins in milk (McLean et al., 1984). From the results in Table 4, and the finding that the effects of genotype were nonsignificant in a combined generalized linear model, we suggest that it is the relative protein concentration that mainly affects the coagulation abil- ity of milk. However, the genotypes seem to have an indirect effect on milk coagulation, as genotypes affect how much protein that is expressed in the milk.

\section{Protein Amounts}

The effects from relative concentration of protein on NC milk (model [2]) are presented in Table 5. The relative concentrations are in close agreement with other studies (Wedholm et al., 2006; Sanchez et al., 2018). Herd, parity, and DIM had no significant effect on relative concentration of protein in model [2] and are not presented in the table. All relative concentrations of protein, except $\alpha_{\mathrm{S}_{1}}-\mathrm{CN}$ and $\alpha_{\mathrm{S}_{2}} \mathrm{CN}$, had a significant effect on $\mathrm{NC}$ milk. The odds ratios for relative concentrations of $\alpha$-LA and $\beta$-CN were $>1$, meaning that the likelihood of having a NC milk sample increases with higher relative concentrations of these 2 proteins. The odds ratios for $\beta$-LG and $\kappa$-CN were $<1$, and therefore the likelihood of $\mathrm{NC}$ milk decreases with an increased relative concentration of $\beta-\mathrm{LG}$ and $\kappa-\mathrm{CN}$ in milk. A lower content of $\kappa-\mathrm{CN}$ in $\mathrm{NC}$ milk has been found in other studies (Hallén et al., 2010; Jensen et al., 2012b; Gustavsson et al., 2014c). In rennet coagulation, $\kappa-\mathrm{CN}$ is a crucial protein, as hydrolysis of $\kappa-\mathrm{CN}$ is the first step of the process (Guinee, 2016). It is therefore reasonable that a higher amount of $\mathrm{k}-\mathrm{CN}$ improves the overall coagulation ability of milk.

Our finding of more NC milk with higher relative concentration of $\alpha$-LA agrees with other studies (Poulsen et al., 2017). This also agrees with studies where a positive correlation between coagulation time and $\alpha$-LA content has been reported (Bonfatti et al., 2011; Ketto et al., 2017). $\alpha$-Lactalbumin has a strong binding site for ionic Ca (Hiraoka et al., 1980; Permyakovand and Berliner, 2000), which is an important ion in the coagulation process. Noncoagulating milk has less ionic Ca than coagulating milk (Table 2). Thus, less ionic $\mathrm{Ca}$ and more $\alpha$-LA that can bind the ionic $\mathrm{Ca}$ could result in lack of ionic Ca in the NC milk. Further, we found that a lower relative concentration of $\beta-\mathrm{LG}$ was associated with increased odds of NC milk (Table 


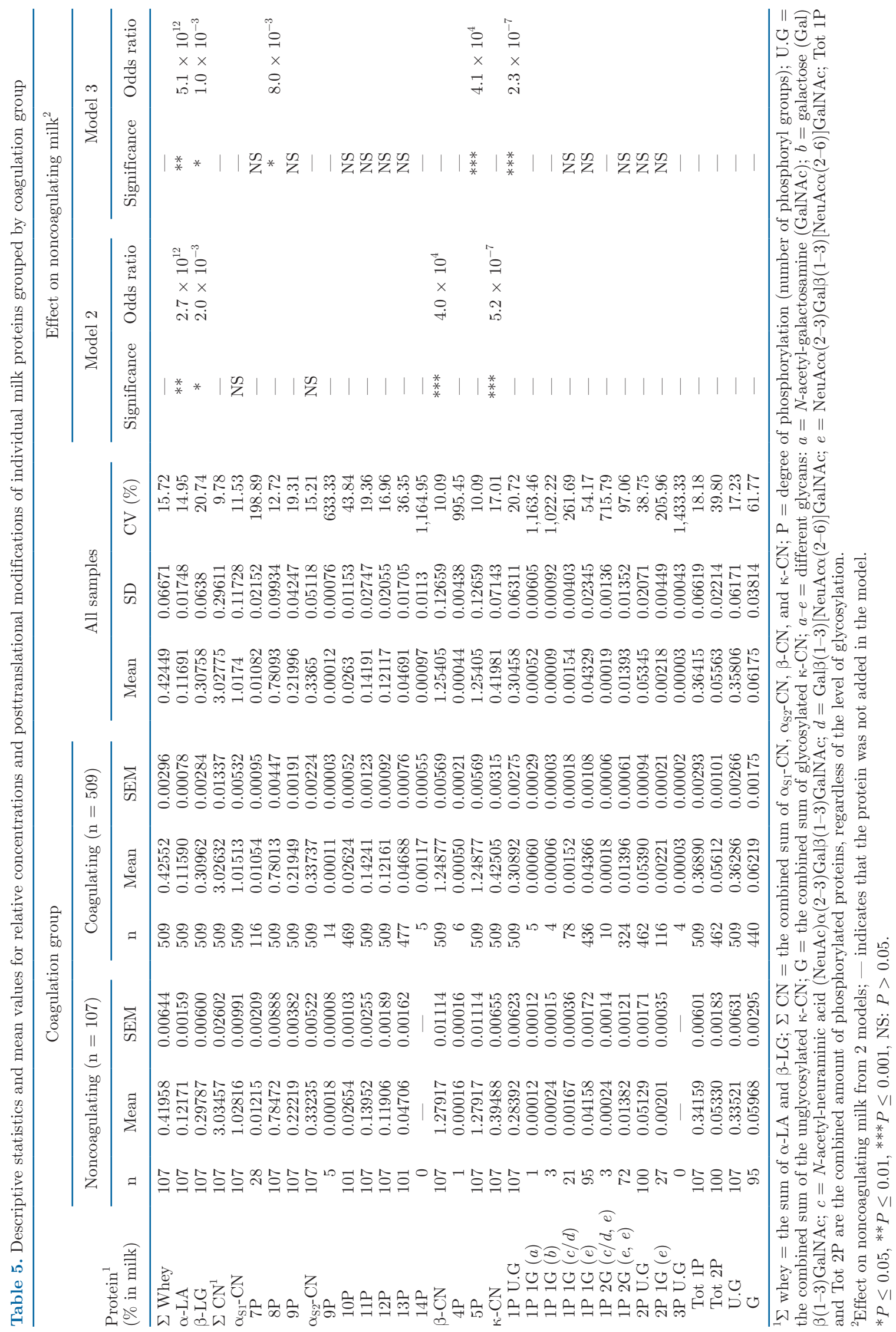




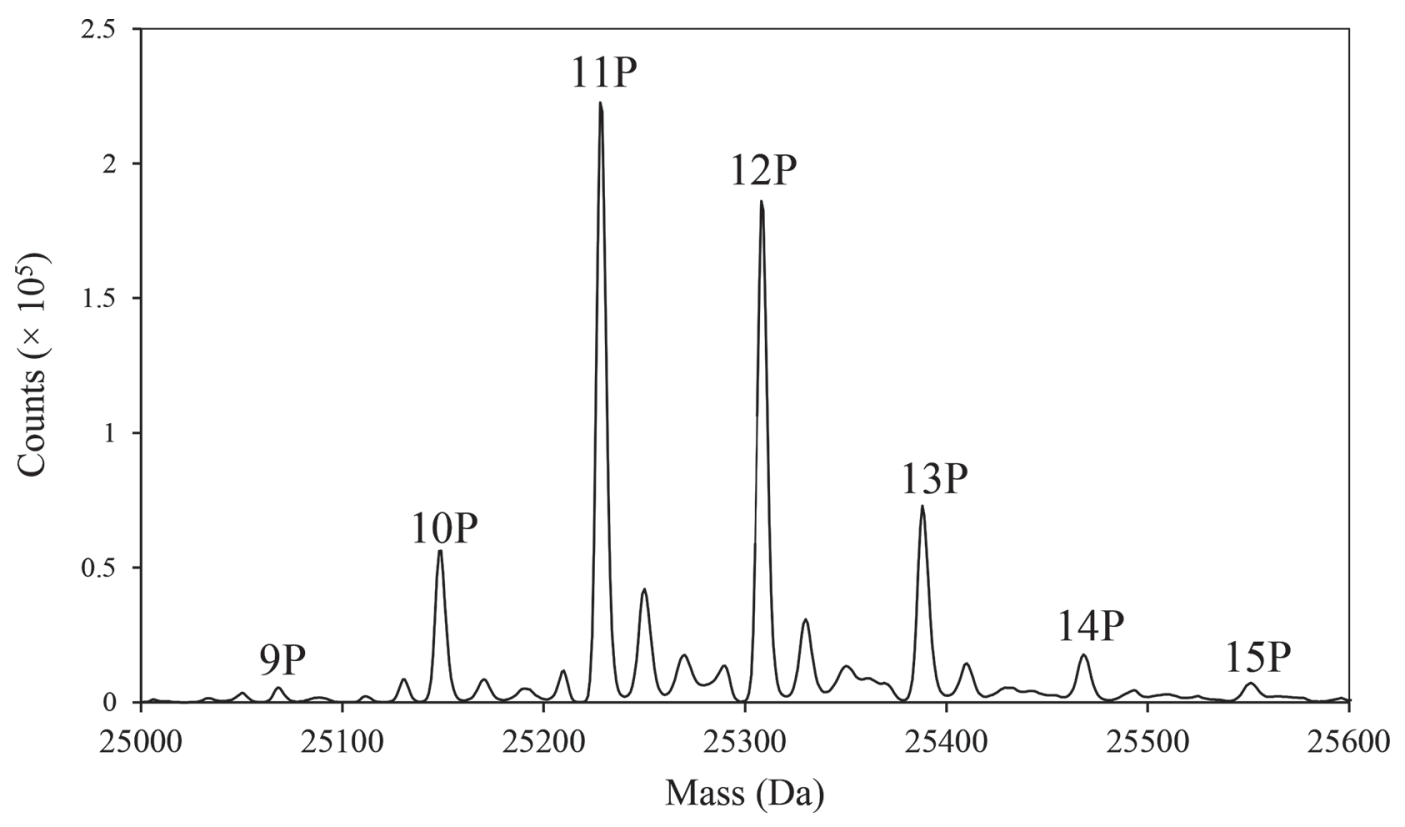

Figure 1. Example of a phosphorylation pattern of $\alpha_{\mathrm{S}_{2}} \mathrm{CN}$ where up to 15 phosphoryl groups $(\mathrm{P})$ were detected.

$5)$. This agrees with other studies where negative correlations were found between $\beta$-LG content and $\mathrm{NC}$ milk or coagulation time (Jõudu et al., 2008; Gustavsson et al., 2014c). Why higher relative concentration of $\beta$-LG would be beneficial to rennet coagulation is unclear, especially in our study where we did not heat treat the milk samples, denaturing the whey proteins. On the contrary, higher whey protein content has been suggested to impair rennet coagulation due to physical or steric inhibition (Gamlath et al., 2018), which agrees with our result for relative concentration of $\alpha$-LA, but not $\beta$-LG.

Higher odds of NC milk with a higher relative concentration of $\beta$-CN agrees with previous studies (Jõudu et al., 2008) where NC milk had a higher proportion of $\beta-\mathrm{CN}$ :CN compared with milk that coagulated well. This also agrees with a study by St-Gelais and Haché (2005) where addition of $\beta$-CN powder to cheese milk worsened the coagulation properties. On the contrary, a higher $\beta$-CN content has also been linked with better coagulation properties (Ketto et al., 2017). The role of $\beta-\mathrm{CN}$ in the coagulation process is therefore unclear. Depending on if the cows are in early or late lactation, $\beta$-CN content can have a positive or negative effect on coagulation properties, such as coagulation time and curd firming time (McDermott et al., 2016).

\section{Posttranslational Modifications of Casein Proteins}

Using MS, we were able to detect many different PTM of CN proteins in the milk samples (Table 5).
We detected 3 different phosphorylations of $\alpha_{\mathrm{S} 1}-\mathrm{CN}$ $(7 \mathrm{P}-9 \mathrm{P})$ and 6 different phosphorylations of $\alpha_{\mathrm{S}_{2}} \mathrm{CN}$ $(9 \mathrm{P}-14 \mathrm{P})$. Also, $15 \mathrm{P}$ of $\alpha_{\mathrm{S}^{2}} \mathrm{CN}$ was detected in the spectra, but due to the large data set, we had to set limitations in the data handling and decided to only include the most abundant proteins. The amount of $15 \mathrm{P}$ is, therefore, not presented in Table 5, but Figure 1 shows an example of a milk sample where phosphorylations $9 \mathrm{P}$ to $15 \mathrm{P}$ were found. The same limitation is applied to glycosylations in $\kappa$ - $\mathrm{CN}$, and Figure 2 shows an example of an extreme milk sample that had several glycosylations in the spectra. Only $1 \mathrm{P} 1 \mathrm{G}(\mathrm{e}), 1 \mathrm{P} 2 \mathrm{G}$ $(\mathrm{e}, \mathrm{e})$, and $2 \mathrm{P} 1 \mathrm{G}(\mathrm{e})$ from this sample were detected in the deconvolution data.

Results from model [3] (effect of PTM on NC milk) are presented in Table 5, and just like model [2], effect of herd, parity, and DIM were all nonsignificant and are not included in the table. No significant effect on $\mathrm{NC}$ milk was found for total relative concentration of $\alpha_{\mathrm{S} 1}-\mathrm{CN}$ in model [2], but in model [3], where effect of the different PTM was investigated, we found a significant effect from relative concentration of $\alpha_{\mathrm{S} 1}-\mathrm{CN}$ $8 \mathrm{P}$ (Table 5). The odds ratio was $<1$, which means that an increase in relative concentration of $\alpha_{\mathrm{S}_{1}} \mathrm{CN} 8 \mathrm{P}$ decreases the odds of having a NC sample. This agrees with previous studies where NC milk was linked with a lower fraction of $\alpha_{\mathrm{S}_{1}}$-CN $8 \mathrm{P}$ compared with coagulating milk (Frederiksen et al., 2011; Jensen et al., 2012b). It also agrees with studies where a higher $\alpha_{\mathrm{S}_{1}}-\mathrm{CN} 8 \mathrm{P}$ content correlated with a shorter coagulation time (Ketto et al., 2017; Amalfitano et al., 2019). Amalfitano et al. 


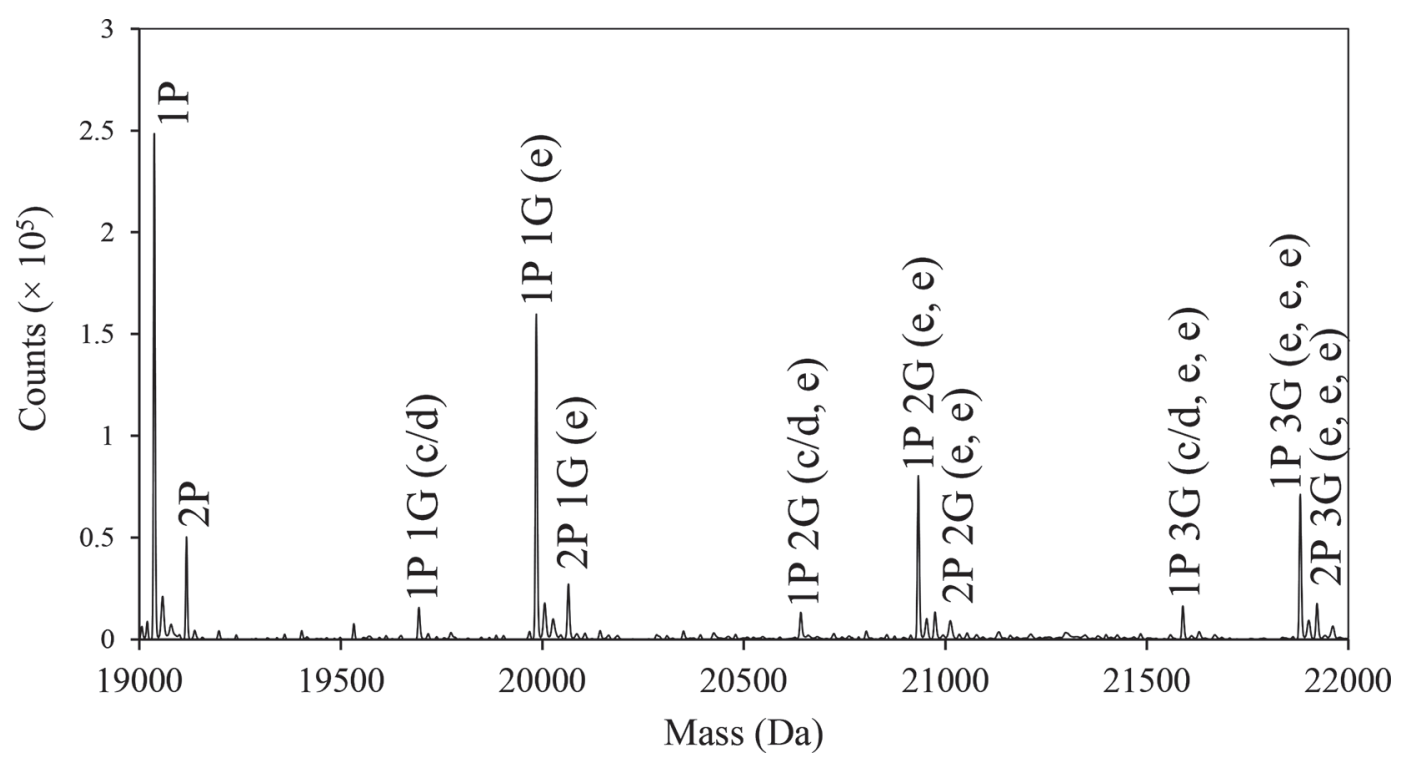

Figure 2. Example of a glycosylation pattern of $\kappa$-CN from an extreme sample that had several glycosylations $(\mathrm{G})$ and phosphorylations $(\mathrm{P})$. a-e represent different glycans: $\mathrm{a}=N$-acetyl-galactosamine (GalNAc); $\mathrm{b}=$ galactose(Gal) $\beta(1-3)$ GalNAc; $\mathrm{c}=N$-acetyl-neuraminic acid(NeuAc) $\alpha(2-3)$ Gal $\beta(1-3)$ GalNAc; $d=\operatorname{Gal} \beta(1-3)[\operatorname{NeuAc} \alpha(2-6)]$ GalNAc; e $=\operatorname{NeuAc} \alpha(2-3)$ Gal $\beta(1-3)[$ NeuAc $\alpha(2-6)]$ GalNAc.

(2019) speculated that the positive effect on coagulation properties from an increased amount of $\alpha_{\mathrm{S}_{1}} \mathrm{CN}$ $8 \mathrm{P}$ (called $\alpha_{\mathrm{S} 1}-\mathrm{CN}$ in their study) is due to the fact that $\alpha_{\mathrm{S}_{1}} \mathrm{CN}$ together with $\beta$-CN are the most abundant proteins in milk, and thereby contributes more material for the coagulum.

Several types of glycosylations and phosphorylations of $\kappa$-CN were identified (Table 5). For the phosphorylations, $91 \%$ of the total milk samples contained $\kappa-\mathrm{CN}$ 2P (562 of 616 milk samples). Only 4 milk samples contained $\kappa-\mathrm{CN} 3 \mathrm{P}$, and all of them were coagulating samples. All samples had the $\mathrm{k}$-CN 1P isoform, while only 17 samples $(3 \%)$ had the 0P isoform. For the glycosylations, $87 \%$ (535 of 616 milk samples) had at least 1 type of glycan attached to a $\kappa-\mathrm{CN}$. We found both к-CN glycosylated with 1 and 2 glycans, but we did not detect any samples with triple glycosylation in the deconvolution data (due to limitations explained earlier). The most frequent glycan identified in the milk samples was glycan e, followed by c/d, b, and a (Table 5 ), which agrees with the literature (Saito and Itoh, 1992). The most common double glycosylation was e, e followed by c/d, e. Results from model [3] showed that the significant effect from $\kappa-\mathrm{CN}$ on $\mathrm{NC}$ milk specifically originated from unglycosylated $\kappa-\mathrm{CN} 1 \mathrm{P}$ (Table 5 ), which is not surprising, as unglycosylated $\kappa-\mathrm{CN} 1 \mathrm{P}$ is the largest fraction of $\kappa-\mathrm{CN}$. This contrasts with a previous study from Bonfatti et al. (2014) where the variation in coagulation time due to $\kappa-\mathrm{CN}$ content was entirely linked to the content of glycosylated $\kappa-\mathrm{CN}$. However, Bonfatti et al. (2014) removed all NC milk samples from the analyses and did not investigate whether glycosylation was affecting $\mathrm{NC}$ milk or not. A study by Poulsen et al. (2016a) showed that fraction of glycosylated $\kappa$-CN is affecting coagulation ability, for which coagulation ability increased with higher fraction of glycosylated $\kappa$-CN, agreeing with Bonfatti et al. (2014). However, in Poulsen et al. (2016a), NC milk samples were included in the analyses and $\mathrm{NC}$ milk was not significantly different from the other coagulation groups. This suggests that a higher glycosylation fraction may be important for the coagulation ability of milk samples that are coagulating, but is not relevant in NC milk.

\section{CONCLUSIONS}

This study investigated protein composition in NC and coagulating milk samples. Compared with coagulating milk, NC milk was associated more with higher $\beta$-LG $A, \beta-\mathrm{CN} A^{2}$, and $\kappa$-CN $A$ alleles. We conclude that the largest effects of genetic variants on $\mathrm{NC}$ milk are indirect effects, as genetic variants affect the relative concentration of protein expressed. Using generalized linear models, NC milk was affected by higher relative concentrations of $\alpha-\mathrm{LA}$ and $\beta-\mathrm{CN}$, as well as lower relative concentrations of $\beta-\mathrm{LG}, \alpha_{\mathrm{S1}^{-}} \mathrm{CN} 8 \mathrm{P}$, and $\kappa-\mathrm{CN}$. Thus, we only found an effect from 1 form of PTM on NC milk. This study has provided insights into the protein composition in NC milk that can be used to improve this undesirable property important for cheese processing. 


\section{ACKNOWLEDGMENTS}

The authors thank Tomas Sandin (Växa Sverige, Sweden) for collection and transportation of the milk samples, and to Chr Hansen A/S (Denmark) for the supply of CHY-MAX Plus to the study. Finally, this study was funded by the Swedish Farmers' Foundation of Agricultural Research, Sweden [grant number O-1520-274] and VikingGenetics, Denmark. The authors have not stated any conflicts of interest.

\section{REFERENCES}

Amalfitano, N., C. Cipolat-Gotet, A. Cecchinato, M. Malacarne, A. Summer, and G. Bittante. 2019. Milk protein fractions strongly affect the patterns of coagulation, curd firming, and syneresis. J. Dairy Sci. 102:2903-2917. https://doi.org/10.3168/jds.2018-15524.

Bijl, E., H. van Valenberg, S. Sikkes, S. Jumelet, G. Sala, K. Olieman, T. van Hooijdonk, and T. Huppertz. 2014. Chymosin-induced hydrolysis of caseins: Influence of degree of phosphorylation of alpha-s1-casein and genetic variants of beta-casein. Int. Dairy J. 39:215-221. https://doi.org/10.1016/j.idairyj.2014.07.005.

Bonfatti, V., A. Cecchinato, L. Gallo, A. Blasco, and P. Carnier. 2011. Genetic analysis of detailed milk protein composition and coagulation properties in Simmental cattle. J. Dairy Sci. 94:5183-5193. https://doi.org/10.3168/jds.2011-4297.

Bonfatti, V., G. Chiarot, and P. Carnier. 2014. Glycosylation of $\kappa$-casein: Genetic and nongenetic variation and effects on rennet coagulation properties of milk. J. Dairy Sci. 97:1961-1969. https:/ /doi.org/10.3168/jds.2013-7418.

Bonfatti, V., L. Grigoletto, A. Cecchinato, L. Gallo, and P. Carnier. 2008. Validation of a new reversed-phase high-performance liquid chromatography method for separation and quantification of bovine milk protein genetic variants. J. Chromatogr. A 1195:101106. https://doi.org/10.1016/j.chroma.2008.04.075.

Caroli, A. M., S. Chessa, and G. J. Erhardt. 2009. Invited review: Milk protein polymorphisms in cattle: Effect on animal breeding and human nutrition. J. Dairy Sci. 92:5335-5352. https://doi.org/10 $.3168 /$ jds.2009-2461.

Fang, Z. H., M. H. P. W. Visker, G. Miranda, A. Delacroix-Buchet, H. Bovenhuis, and P. Martin. 2016. The relationships among bovine $\alpha \mathrm{S}$-casein phosphorylation isoforms suggest different phosphorylation pathways. J. Dairy Sci. 99:8168-8177. https://doi.org/10 $.3168 /$ jds.2016-11250.

Farrell, H. M. Jr., R. Jimenez-Flores, G. T. Bleck, E. M. Brown, J. E. Butler, L. K. Creamer, C. L. Hicks, C. M. Hollar, K. F. Ng-KwaiHang, and H. E. Swaisgood. 2004. Nomenclature of the proteins of cows' milk - Sixth revision. J. Dairy Sci. 87:1641-1674. https://doi .org/10.3168/jds.S0022-0302(04)73319-6.

Fox, P. F., and P. L. H. McSweeney. 2017. Cheese: An Overview, 4th ed. P. L. H. McSweeney, P. F. Fox, P. D. Cotter, and D. W. Everett, ed. Elsevier Ltd., London, UK.

Frederiksen, P. D., K. K. Andersen, M. Hammershøj, H. D. Poulsen, J. Sørensen, M. Bakman, K. B. Qvist, and L. B. Larsen. 2011. Composition and effect of blending of noncoagulating, poorly coagulating, and well-coagulating bovine milk from individual Danish Holstein cows. J. Dairy Sci. 94:4787-4799. https://doi.org/10 $.3168 /$ jds.2011-4343.

Gamlath, C. J., T. S. H. Leong, M. Ashokkumar, and G. J. O. Martin. 2018. The inhibitory roles of native whey protein on the rennet gelation of bovine milk. Food Chem. 244:36-43. https://doi.org/ 10.1016/j.foodchem.2017.10.029.

Guinee, T. P. 2016. Protein in Cheese and Cheese Products: StructureFunction Relationships, 4th ed. P. L. H. McSweeney and J. A. O'Mahony, ed. Springer, New York, NY.

Gustavsson, F., A. J. Buitenhuis, M. Glantz, H. Stålhammar, H. Lindmark Månsson, N. A. Poulsen, L. B. Larsen, A. Andrén, and M. Paulsson. 2014a. Impact of genetic variants of milk proteins on chymosin-induced gelation properties of milk from individual cows of Swedish Red dairy cattle. Int. Dairy J. 39:102-107. https://doi .org/10.1016/j.idairyj.2014.05.007.

Gustavsson, F., M. Glantz, A. J. Buitenhuis, H. Lindmark Månsson, H. Stålhammar, A. Andrén, and M. Paulsson. 2014b. Factors influencing chymosin-induced gelation of milk from individual dairy cows: Major effects of casein micelle size and calcium. Int. Dairy J. 39:201-208. https://doi.org/10.1016/j.idairyj.2014.06.011.

Gustavsson, F., M. Glantz, N. A. Poulsen, L. Wadsö, H. Stålhammar, A. Andrén, H. Lindmark Månsson, L. B. Larsen, M. Paulsson, and W. F. Fikse. 2014c. Genetic parameters for rennet- and acidinduced coagulation properties in milk from Swedish Red dairy cows. J. Dairy Sci. 97:5219-5229. https://doi.org/10.3168/jds.2014 $-7996$.

Hallén, E., A. Lundén, A.-M. Tyrisevä, M. Westerlind, and A. Andrén. 2010. Composition of poorly and non-coagulating bovine milk and effect of calcium addition. J. Dairy Res. 77:398-403. https://doi .org/10.1017/S0022029910000671.

Heck, J. M. L., A. Schennink, H. J. F. Van Valenberg, H. Bovenhuis, M. H. P. W. Visker, J. A. M. Van Arendonk, and A. C. M. Van Hooijdonk. 2009. Effects of milk protein variants on the protein composition of bovine milk. J. Dairy Sci. 92:1192-1202. https:// doi.org/10.3168/jds.2008-1208.

Hiraoka, Y., T. Segawa, K. Kuwajima, S. Sugai, and N. Murai. 1980. $\alpha$-Lactalbumin: A calcium metalloprotein. Biochem. Biophys. Res. Commun. 95:1098-1104. https://doi.org/10.1016/0006 $-291 \mathrm{X}(80) 91585-5$.

Holland, J. W., and M. J. Boland. 2014. Post-translational Modifications of Caseins. 2nd ed. H. Singh, M. J. Boland, and A. Thompson, ed. Elsevier Inc., London, UK.

Jensen, H. B., J. W. Holland, N. A. Poulsen, and L. B. Larsen. 2012a. Milk protein genetic variants and isoforms identified in bovine milk representing extremes in coagulation properties. J. Dairy Sci. 95:2891-2903. https://doi.org/10.3168/jds.2012-5346.

Jensen, H. B., K. S. Pedersen, L. B. Johansen, N. A. Poulsen, M. Bakman, D. E. W. Chatterton, and L. B. Larsen. 2015. Genetic variation and posttranslational modification of bovine $\kappa$-casein: Effects on caseino-macropeptide release during renneting. J. Dairy Sci. 98:747-758. https://doi.org/10.3168/jds.2014-8678.

Jensen, H. B., N. A. Poulsen, K. K. Andersen, M. Hammersh øj, H. D. Poulsen, and L. B. Larsen. 2012b. Distinct composition of bovine milk from Jersey and Holstein-Friesian cows with good, poor, or noncoagulation properties as reflected in protein genetic variants and isoforms. J. Dairy Sci. 95:6905-6917. https://doi.org/10.3168/ jds.2012-5675.

Jõudu, I., M. Henno, T. Kaart, T. Püssa, and O. Kärt. 2008. The effect of milk protein contents on the rennet coagulation properties of milk from individual dairy cows. Int. Dairy J. 18:964-967. https: //doi.org/10.1016/j.idairyj.2008.02.002.

Ketto, I. A., T. M. Knutsen, J. Øyaas, B. Heringstad, T. Ådnøy, T.G. Devold, and S. B. Skeie. 2017. Effects of milk protein polymorphism and composition, casein micellesize and salt distribution on the milk coagulation properties in Norwegian Red cattle. Int. Dairy J. 70:55-64. https://doi.org/10.1016/j.idairyj.2016.10.010.

Léonil, J., D. Mollé, F. Gaucheron, P. Arpino, P. Guénot, and J. L. Maubois. 1995. Analysis of major bovine milk proteins by on-line high-performance liquid chromatography and electrospray ionization-mass spectrometry. Lait 75:193-210. https://doi.org/10.1051/ lait:1995314.

Lien, S., J. Kantanen, I. Olsaker, L. E. Holm, E. Eythorsdottir, K. Sandberg, B. Dalsgard, and S. Adalsteinsson. 1999. Comparison of milk protein allele frequencies in nordic cattle breeds. Anim. Genet. 30:85-91. https://doi.org/10.1046/j.1365-2052.1999.00434.x.

McDermott, A., G. Visentin, M. De Marchi, D. P. Berry, M. A. Fenelon, P. M. O'Connor, O. A. Kenny, and S. McParland. 2016. Prediction of individual milk proteins including free amino acids in bovine milk using mid-infrared spectroscopy and their correlations with milk processing characteristics. J. Dairy Sci. 99:3171-3182. https://doi.org/10.3168/jds.2015-9747.

McLean, D. M., B. E. R. Graham, R. W. Ponzoni, and H. A. McKenzie. 1984. Effects of milk protein genetic variants on milk yield and 
composition. J. Dairy Res. 51:531-546. https://doi.org/10.1017/ S0022029900032854.

Minkiewicz, P., C. J. Slangen, F. M. Lagerwerf, J. Haverkamp, H. S. Rollema, and S. Visser. 1996. Reversed-phase high-performance liquid chromatographic separation of bovine $\kappa$-casein macropeptide and characterization of isolated fractions. J. Chromatogr. A 743:123-135. https://doi.org/10.1016/0021-9673(96)00122-7.

Nilsson, K., H. Stålhammar, M. Stenholdt Hansen, H. LindmarkMånsson, S. Duchemin, F. Fikse, D. J. de Koning, M. Paulsson, and M. Glantz. 2019. Characterisation of non-coagulating milk and effects of milk composition and physical properties on rennetinduced coagulation in Swedish Red Dairy Cattle. Int. Dairy J. 95:50-57. https://doi.org/10.1016/j.idairyj.2019.03.006.

Permyakov, E. A., and L. J. Berliner. 2000. $\alpha$-Lactalbumin: Structure and function. FEBS Lett. 473:269-274. https://doi.org/10.1016/ S0014-5793(00)01546-5.

Poulsen, N. A., H. P. Bertelsen, H. B. Jensen, F. Gustavsson, M. Glantz, H. Lindmark Månsson, A. Andrén, M. Paulsson, C. Bendixen, A. J. Buitenhuis, and L. B. Larsen. 2013. The occurrence of noncoagulating milk and the association of bovine milk coagulation properties with genetic variants of the caseins in 3 Scandinavian dairy breeds. J. Dairy Sci. 96:4830-4842. https://doi.org/10 .3168/jds.2012-6422.

Poulsen, N. A., M. Glantz, A. K. Rosengaard, M. Paulsson, and L. B. Larsen. 2017. Comparison of milk protein composition and rennet coagulation properties in native Swedish dairy cow breeds and high-yielding Swedish Red cows. J. Dairy Sci. 100:8722-8734. https://doi.org/10.3168/jds.2017-12920.

Poulsen, N. A., H. B. Jensen, and L. B. Larsen. 2016a. Factors influencing degree of glycosylation and phosphorylation of caseins in individual cow milk samples. J. Dairy Sci. 99:3325-3333. https:// doi.org/10.3168/jds.2015-10226.

Poulsen, N. A., A. K. Rosengaard, B. D. Szekeres, V. R. Gregersen, H. B. Jensen, and L. B. Larsen. 2016b. Protein heterogeneity of bovine $\beta$-casein in Danish dairy breeds and association of rare $\beta$-casein F with milk coagulation properties. Acta Agric. Scand. Anim. Sci. 66:190-198. https://doi.org/10.1080/09064702.2017 .1342858

Rauh, V. M., L. B. Johansen, M. Bakman, R. Ipsen, M. Paulsson, L. B. Larsen, and M. Hammershøj. 2015. Protein lactosylation in
UHT milk during storage measured by liquid chromatographymass spectrometry and quantification of furosine. Int. J. Dairy Technol. 68:486-494. https://doi.org/10.1111/1471-0307.12265.

Raynes, J. K., L. Day, M. A. Augustin, and J. A. Carver. 2015. Structural differences between bovine A1 and A2 $\beta$-casein alter micelle self-assembly and influence molecular chaperone activity. J. Dairy Sci. 98:2172-2182. https://doi.org/10.3168/jds.2014-8800.

Saito, T., and T. Itoh. 1992. Variations and distributions of O-glycosidically linked sugar chains in bovine $\kappa$-casein. J. Dairy Sci. 75:1768-1774. https://doi.org/10.3168/jds.S0022-0302(92)77936 $-3$.

Sanchez, M. P., M. El Jabri, S. Minéry, V. Wolf, E. Beuvier, C. Laithier, A. Delacroix-Buchet, M. Brochard, and D. Boichard. 2018 Genetic parameters for cheese-making properties and milk composition predicted from mid-infrared spectra in a large data set of Montbéliarde cows. J. Dairy Sci. 101:10048-10061. https://doi .org/10.3168/jds.2018-14878.

Sandra, S., M. Alexander, and D. G. Dalgleish. 2007. The rennet coagulation mechanism of skim milk as observed by transmission diffusing wave spectroscopy. J. Colloid Interface Sci. 308:364-373. https://doi.org/10.1016/j.jcis.2007.01.021.

St-Gelais, D., and S. Haché. 2005. Effect of $\beta$-casein concentration in cheese milk on rennet coagulation properties, cheese composition and cheese ripening. Food Res. Int. 38:523-531. https://doi.org/10 $.1016 /$ j.foodres.2004.11.006.

Vreeman, H. J., S. Visser, C. J. Slangen, and J. A. Van Riel. 1986. Characterization of bovine kappa-casein fractions and the kinetics of chymosin-induced macropeptide release from carbohydrate-free and carbohydrate-containing fractions determined by high-performance gel-permeation chromatography. Biochem. J. 240:87-97. https://doi.org/10.1042/bj2400087.

Walstra, P., J. T. M. Wouters, and T. J. Geurts. 2006. Dairy Science and Technology, 2nd ed. Taylor \& Francis Group, Boca Raton, FL

Wedholm, A., L. B. Larsen, H. Lindmark-Månsson, A. H. Karlsson, and A. Andrén. 2006. Effect of protein composition on the cheesemaking properties of milk from individual dairy cows. J. Dairy Sci. 89:3296-3305. https://doi.org/10.3168/jds.S0022-0302(06)72366 -9 . 